\title{
Metabolizable energy requirement for maintenance estimated by regression analysis of body weight gain or metabolizable energy intake in growing pigs
}

\author{
Hu Liu', Yifan Chen ${ }^{1}$, Zhongchao Li ${ }^{1}$, Yakui Li ${ }^{1}$, Changhua Lai ${ }^{1}$ Xiangshu Piao ${ }^{1}$, \\ Jaap van Milgen², and Fenglai Wang ${ }^{1, *}$
}

\section{* Corresponding Author: Fenglai Wang Tel: +86-10-62733586, Fax: +86-10-62733688, E-mail: wangfl@cau.edu.cn}

'State Key Laboratory of Animal Nutrition, College of Animal Science and Technology, China Agricultural University, Beijing 100193, China

${ }^{2}$ INRA, UMR Pegase, 35590 Saint-Gilles, France

ORCID

Hu Liu

https://orcid.org/0000-0002-0854-3371

Yifan Chen

https://orcid.org/0000-0002-9694-3219

Zhongchao Li

https://orcid.org/0000-0002-4488-8756 Yakui Li

https://orcid.org/0000-0003-0161-5691

Changhua Lai

https://orcid.org/0000-0002-6736-7179

Xiangshu Piao

https://orcid.org/0000-0003-2240-5773

Jaap van Milgen

https://orcid.org/0000-0002-6131-5255

Fenglai Wang

https://orcid.org/0000-0002-7538-0082

Submitted Dec 13, 2017; Revised Apr 2, 2018; Accepted Jan 8, 2019
Objective: Feed energy required for pigs is first prioritized to meet maintenance costs. Additional energy intake in excess of the energy requirement for maintenance is retained as protein and fat in the body, leading to weight gain. The objective of this study was to estimate the metabolizable energy requirements for maintenance $\left(\mathrm{ME}_{\mathrm{m}}\right)$ by regressing body weight $(\mathrm{BW})$ gain against metabolizable energy intake (MEI) in growing pigs.

Methods: Thirty-six growing pigs $(26.3 \pm 1.7 \mathrm{~kg})$ were allotted to 1 of 6 treatments with 6 replicates per treatment in a randomized complete block design. Treatments were 6 feeding levels which were calculated as $50 \%, 60 \%, 70 \%, 80 \%, 90 \%$, or $100 \%$ of the estimated ad libitum MEI $\left(2,400 \mathrm{~kJ} / \mathrm{kg} \mathrm{BW}^{0.60} \mathrm{~d}\right)$. All pigs were individually housed in metabolism crates for $30 \mathrm{~d}$ and weighed every $5 \mathrm{~d}$. Moreover, each pig from each treatment was placed in the open-circuit respiration chambers to measure heat production $(\mathrm{HP})$ and energy retained as protein $\left(\mathrm{RE}_{\mathrm{p}}\right)$ and fat $\left(\mathrm{RE}_{\mathrm{f}}\right)$ every $5 \mathrm{~d}$. Serum biochemical parameters of pigs were analyzed at the end of the experiment.

Results: The average daily gain (ADG) and $\mathrm{HP}$ as well as the $\mathrm{RE}_{\mathrm{p}}$ and $\mathrm{RE}_{\mathrm{f}}$ linearly increased with increasing feed intake $(p<0.010)$. $\beta$-hydroxybutyrate concentration of serum tended to increase with increasing feed intake $(\mathrm{p}=0.080)$. The regression equations of MEI on ADG were MEI, $\mathrm{kJ} / \mathrm{kg} \mathrm{BW}{ }^{0.60} \mathrm{~d}=1.88 \times \mathrm{ADG}, \mathrm{g} / \mathrm{d}+782\left(\mathrm{R}^{2}=0.86\right)$ and $\mathrm{ME}_{\mathrm{m}}$ was estimated at 782 $\mathrm{kJ} / \mathrm{kg} \mathrm{BW}{ }^{0.60} \mathrm{~d}$. Protein retention of growing pigs would be positive while $\mathrm{RE}_{\mathrm{f}}$ would be negative at this feeding level via regression equations of $\mathrm{RE}_{\mathrm{p}}$ and $\mathrm{RE}_{\mathrm{f}}$ on MEI.

Conclusion: The $\mathrm{ME}_{\mathrm{m}}$ was estimated at $782 \mathrm{~kJ} / \mathrm{kg} \mathrm{BW}^{0.60} \mathrm{~d}$ in current experiment. Furthermore, growing pigs will deposit protein and oxidize fat if provided feed at the estimated maintenance level.

Keywords: Fat; Growing Pigs; Indirect Calorimetry; Maintenance Energy Requirement; Protein

\section{INTRODUCTION}

Feed energy required for pigs is first prioritized to meet maintenance costs [1]. Maintenance comprises the basal energy requirements for supporting body function, body temperature and necessary activity at a time when there is no net gain or loss of tissue [2]. Maintenance energy requirement should be independent of the animal's production state and nutritional levels, and therefore, it should be related to animal characteristics only [3]. Furthermore, the energy requirement for maintenance is an important part of net energy (NE) system, and accuracy of estimation of the energy requirements for maintenance will influence the absolute NE value of a feed ingredient [4-6]. 
Energy requirements for maintenance can be estimated using body weight (BW) gain as an indirect index of energy retention by the regression analysis method $[4,5]$. Yuliarty et al [6] reported that metabolizable energy requirements for maintenance $\left(\mathrm{ME}_{\mathrm{m}}\right)$ of entire male Bali cattle in East Timor determined by regressing BW change against metabolizable energy intake (MEI). Compared to the method of determination the heat leaving the animal's body, one advantage of this method is that the measurement of BW can be very precise [7]. Moreover, compared with fasting method, measurements can be obtained in a relatively healthy physiological state, which might decrease variability in the energy concentration of tissue gain [7].

Numerous studies determined the effects of various MEI levels on heat production (HP) by graded feed intake of identical diet $[3,8]$. However, increasing feed intake increased not only MEI, but also other nutrients as protein and fat. Thus, the effects of feeding level on digestibility and nitrogen and energy balances in growing pigs were determined $[9,10]$. Furthermore, additional energy intake in excess of the $\mathrm{ME}_{\mathrm{m}}$ is retained as protein $\left(\mathrm{RE}_{\mathrm{p}}\right)$ and fat $\left(\mathrm{RE}_{\mathrm{f}}\right)$ in the body [11]. However, little is known of the effects of feeding level on the energy retention for protein and fat in growing pigs. A series of studies have demonstrated that feeding level plays a role in blood biochemistry [12]. The serum biochemical parameters related to lipid metabolism and protein metabolism could be reflected the energy deposition and mobilization [13].

Therefore, the objective of this experiment was to estimate $\mathrm{ME}_{\mathrm{m}}$ in growing pigs by regressing BW gain against MEI. In addition, the effects of feeding level on the nitrogen and energy balance were also measured.

\section{MATERIALS AND METHODS}

The experimental protocol used in the present study was approved by the Institutional Animal Care and Use Committee at China Agricultural University (Beijing, China).

\section{Equipment}

To determine the components of energy metabolism, 6 opencircuit respiration chambers $\left(7.8 \mathrm{~m}^{3}\right.$ in volume $)$ were used. The design of the chambers was previously reported by Zhang et al [14]. By means of a gas-tight ventilator, fresh air was drawn into the chambers where it was thoroughly mixed with the air in the chamber. The chambers were air-conditioned to maintain a constant temperature of $22^{\circ} \mathrm{C}$ at approximately $70 \%$ relative humidity. Temperature and atmospheric pressure in the chamber were measured and used to calculate gas extraction rate under standard temperature $\left(0^{\circ} \mathrm{C}\right)$ and pressure $(101$ $\mathrm{kPa}$ ). Concentrations of oxygen inside and outside the chamber were measured with a Paramagnetic Differential Gas Analyzer (Oxymat 6E, Siemens, Munich, Germany), and concentra- tions of $\mathrm{CO}_{2}, \mathrm{CH}_{4}$, and $\mathrm{NH}_{3}$ were measured with Infrared Gas Analyzers (Ultramat 6E, Siemens, Germany).

All measurements of airflow, gas composition, and climatic conditions in the chambers were conducted at 5-min intervals for calculations of gas exchange. Two respiration chambers shared one gas analyzer. Analyzers had a range of determination of $19.5 \%$ to $21 \%$ for $\mathrm{O}_{2}, 0 \%$ to $1 \%$ for $\mathrm{CO}_{2}, 0 \%$ to $0.1 \%$ for $\mathrm{CH}_{4}$, and $0 \%$ to $0.1 \%$ for $\mathrm{NH}_{3}$ with a sensitivity of $0.2 \%$ within the determination range. The airflow of extraction was measured by a Mass Flow Meter (Alicat, Tucson, AZ, USA).

\section{Animals, diets and experimental design}

Thirty-six growing barrows (Duroc $\times$ Landrace $\times$ Yorkshire) with an average initial BW of $26.3 \pm 1.7 \mathrm{~kg}$ were selected from the Fengning Swine Research farm of China Agricultural University (Hebei, China), and the experiment was conducted for $30 \mathrm{~d}$. Pigs were stratified by BW into 6 blocks of 6 pigs for each treatment. Block 1 comprised the heaviest 6 pigs while block 6 comprised the lightest 6 pigs. Within each block, the pigs were randomly assigned to 1 of 6 feeding levels in a randomized complete block design to give 6 replicates per level for the entire experiment. The feeding levels represented a targeted daily intake of $50 \%, 60 \%, 70 \%, 80 \%, 90 \%$, or $100 \%$ of their estimated ad libitum MEI $\left(2,400 \mathrm{~kJ} / \mathrm{kg} \mathrm{BW}^{0.60} \mathrm{~d}\right)[14,15]$. The basal diet was formulated based on corn and soybean meal for growing pigs (Table 1).

The experiment in the respiration chambers was conducted in 6 periods of $5 \mathrm{~d}$. During each period, 6 pigs chosen from 6 feeding level were placed in the open-circuit respiration chambers. Pigs assigned in the same block were placed in the respiration chambers at the same period. Therefore, 6 pigs in block 1 were placed in the chamber during the first period, and 6 pigs in block 6 were placed in the chamber during the last period. This procedure was chosen to minimize the effects of BW on the parameters measured.

Pigs and given feeds were weighed at the start and end of each period to calculate average daily gain (ADG) and to determine the actual amount of feed consumed during each period. Body weight gain and feed consumption were used to estimate gain-to-feed ratio (G:F).

All pigs were individually housed in stainless steel metabolic crates during the entire $30 \mathrm{~d}$ experiment. During the time that pigs were not in the respiration chambers, they were housed in an adjacent room under similar environmental conditions as those in the respiration chambers.

All pigs received their assigned feeding level throughout the $30 \mathrm{~d}$ experiment. Pigs were fed an equal amount of meal twice daily at 0900 and 1530 with free access to water. The actual amounts of feed were based on the body weight of pigs at the start of each period. Feed refusals and spillage were recorded daily. 
Table 1. Ingredient and analyzed nutrient composition of the experimental diet (as-fed basis)

\begin{tabular}{lc}
\hline Item & Basal diet \\
\hline Ingredient (\%) & \\
Corn & 71.00 \\
Soybean meal, 43\% CP & 23.00 \\
Wheat bran & 2.70 \\
Dicalcium phosphate & 1.10 \\
Limestone & 0.95 \\
L-lysine·HCl, 78\% & 0.40 \\
Salt & 0.35 \\
Vitamins and minerals premix ${ }^{1)}$ & 0.50 \\
Analyzed nutrient composition (\%) & \\
Crude protein & 15.88 \\
Ether extract & 2.66 \\
Crude fiber & 2.75 \\
Calcium & 0.68 \\
Total phosphorus & 0.55 \\
Lysine & 1.02 \\
Methionine+cysteine & 0.57 \\
Tryptophan & 0.17 \\
Threonine & 0.60 \\
GE (MJ/kg) & 16.02 \\
ME (MJ/kg) & 13.98 \\
\hline
\end{tabular}

$\mathrm{CP}$, crude protein; $\mathrm{GE}$, gross energy; $\mathrm{ME}$, metabolizable energy.

1) Vitamin-mineral premix supplied the following nutrients per kilogram of diet: vitamin $\mathrm{A}$, 5,512 IU; vitamin $\mathrm{D}_{3}$, 2,200 IU; vitamin $\mathrm{E}$, $30 \mathrm{lU}$; vitamin $\mathrm{K}_{3}, 2.2 \mathrm{mg}$; vitamin $B_{12}, 27.6 \mu$; riboflavin, 4 mg; pantothenic acid, 14 mg; niacin, $30 \mathrm{mg}$; choline chloride, $400 \mathrm{mg}$; folic acid, $0.7 \mathrm{mg}$; thiamine, $1.5 \mathrm{mg}$; pyridoxine, $3 \mathrm{mg}$; biotin, 44 ug; $\mathrm{Mn}(\mathrm{MnO}), 40 \mathrm{mg}$; Fe (FeSO $\left.\mathrm{F}_{4} \cdot \mathrm{H}_{2} \mathrm{O}\right), 75 \mathrm{mg} ; \mathrm{Zn}(\mathrm{ZnO}), 75 \mathrm{mg} ; \mathrm{Cu}$ $\left(\mathrm{CuSO}_{4} \cdot 5 \mathrm{H}_{2} \mathrm{O}\right), 100 \mathrm{mg} ; \mathrm{I}(\mathrm{KI}), 0.3 \mathrm{mg} ; \mathrm{Se}\left(\mathrm{Na}_{2} \mathrm{SeO}_{3}\right), 0.3 \mathrm{mg}$.

${ }^{2)}$ Metabolizable energy content of the diet was calculated using energy values for the ingredients obtained from NRC [51].

\section{Sample collection}

Feces and urine were collected only during the period when pigs were in the respiration chambers according to the methods described by Liu et al [8]. Feces samples were sealed in plastic bags and stored at $-20^{\circ} \mathrm{C}$. Urine was collected every morning for each pig into plastic buckets containing $50 \mathrm{~mL}$ of $6 \mathrm{~N} \mathrm{HCl}$ and sieved with cotton gauze and filtered into a plastic bottle every day. The total quantity of collected urine was weighed, and $5 \%$ of the daily urinary excretion was stored at $-20^{\circ} \mathrm{C}$.

At the end of the experiment, feces and urine were thawed and separately mixed for each animal and a sub-sample was collected for analysis. Fecal samples were oven-dried for $72 \mathrm{~h}$ at $65^{\circ} \mathrm{C}$. The feed and dried fecal samples were ground through a 1-mm screen and mixed thoroughly for chemical analysis. A $4 \mathrm{~mL}$ urine sample was dripped on to 2 filter papers in a special crucible and dried for $8 \mathrm{~h}$ at $65^{\circ} \mathrm{C}$ in a drying oven.

Concentrations of $\mathrm{O}_{2}, \mathrm{CO}_{2}$, and $\mathrm{CH}_{4}$ in ingoing and outgoing air, and outgoing air flow rates were measured during the period when pigs were placed in the respiration chambers. These values were used to calculate $\mathrm{O}_{2}$ consumption and $\mathrm{CO}_{2}$ and $\mathrm{CH}_{4}$ production.
Blood samples were collected from each pig via the anterior vena cava into $10-\mathrm{mL}$ tubes containing no anticoagulant (Becton Dickinson Vacutainer Systems, Franklin Lakes, NJ, USA) at the end of the experiment following a 12-h fast. Samples were centrifuged (Biofuge22R; Heraeus, Hanau, Germany) at $3,000 \times \mathrm{g}$ for $10 \mathrm{~min}$, and the serum was stored at $-80^{\circ} \mathrm{C}$ until analyzed.

\section{Chemical analysis}

All chemical analyses were conducted in duplicate. Samples of ingredients, diets and feces were analyzed for dry matter (DM, method 930.15, AOAC [16]), crude protein (CP, method 984.13, AOAC [16]), crude fiber (method 978.10, AOAC [16]), calcium (method 927.02, AOAC [16]), total phosphorus (method 984.27, AOAC [16]), and ether extract (Thiex et al [17]). Gross energy in diets, feces and urine were measured using an isoperibol bomb calorimeter (Parr 6400 Calorimeter, Moline, IL, USA) according to Zhang et al [14].

Analysis of amino acid (AA) content in the ingredients and diets was conducted according to Li et al [18]. For most AA, not including methionine, cysteine and tryptophan, samples were analyzed after $6 \mathrm{~N} \mathrm{HCl} \mathrm{hydrolysis} \mathrm{for} 24 \mathrm{~h}$ at $110^{\circ} \mathrm{C}$ using an amino acid analyzer (Hitachi L-8800, Hitachi, Ltd., Tokyo, Japan). Methionine and cysteine were determined as methionine sulfone and cysteic acid, respectively, after cold performic acid oxidation overnight and hydrolysis with $7.5 \mathrm{~N} \mathrm{HCl}$ for $24 \mathrm{~h}$ at $110^{\circ} \mathrm{C}$. Tryptophan was analyzed after $\mathrm{LiOH}$ hydrolysis for $22 \mathrm{~h}$ at $110^{\circ} \mathrm{C}$ using high-performance liquid chromatography (Agilent 1200 Series; Agilent Technologies Incorporated, Santa Clara, CA, USA).

After the frozen serum samples were thawed at $4^{\circ} \mathrm{C}$, serum concentrations of glucose, serum urea nitrogen (SUN), creatinine, triglyceride, free fatty acids (FFA) and $\beta$-hydroxybutyric acid (BHBA) were quantified using an automatic biochemical analyzer (Hitachi 7160, Hitachi, Ltd., Japan) at the Beijing Sino-UK institute of Biological Technology (Beijing, China). Leptin concentration was assayed using a radioimmunoassay method following the manufacturer's instructions (Sino-UK institute of Biological Technology, China).

\section{Calculations}

The apparent total tract digestibilities (ATTD) of DM, CP, and gross energy (GE) were calculated according to standard procedures [19]. The digestible energy (DE) content of diet was calculated as the difference between GE intake and the energy lost in feces. Methane loss was negligible and therefore was ignored when the ME content was determined which corresponded to the difference between DE and the energy lost in urine [19].

The HP, non-protein respiratory quotient $\left(\mathrm{RQ}_{\mathrm{np}}\right)$, and $\mathrm{RQ}$ were calculated daily from $\mathrm{O}_{2}$ consumption, as well as $\mathrm{CO}_{2}$ and $\mathrm{CH}_{4}$ production and nitrogen excretion in urine (UN) 
during the 5- $\mathrm{d}$ balance period according to the following formulas by Brouwer et al [20]:

$$
\begin{gathered}
\mathrm{HP}(\mathrm{kJ})=16.1753 \times \mathrm{O}_{2}(\mathrm{~L})+5.0208 \times \mathrm{CO}_{2}(\mathrm{~L}) \\
-2.1673 \times \mathrm{CH}_{4}(\mathrm{~L})-5.9873 \times \mathrm{UN}(\mathrm{g}) \\
\mathrm{RQ}_{\mathrm{np}}=\left[\left(\mathrm{CO}_{2}(\mathrm{~L})-\mathrm{UN}(\mathrm{g}) \times 6.25 \times 0.774\right)\right. \\
\left./\left(\mathrm{O}_{2}(\mathrm{~L})-\mathrm{UN}(\mathrm{g}) \times 6.25 \times 0.957\right)\right] \\
\mathrm{RQ}=\mathrm{CO}_{2}(\mathrm{~L}) / \mathrm{O}_{2}(\mathrm{~L})
\end{gathered}
$$

Oxidation of protein (OXP) and oxidation of carbohydrate (OXCHO) were calculated by the method described by Chwalibog et al [21] and validated for $\mathrm{RQ}_{\mathrm{np}}$ values above and below 1.00 by Chwalibog et al [22] as:

$$
\begin{aligned}
& \operatorname{OXP}(\mathrm{kJ})=\mathrm{UN}(\mathrm{g}) \times 6.25 \times 18.42 \\
& \begin{aligned}
\mathrm{OXCHO}(\mathrm{kJ})=[ & -2.968 \times \mathrm{O}_{2}(\mathrm{~L})+4.147 \times \mathrm{CO}_{2}(\mathrm{~L})-1.761 \\
& \left.\times \mathrm{CH}_{4}(\mathrm{~L})-2.446 \times \mathrm{UN}(\mathrm{g})\right] \times 17.58
\end{aligned}
\end{aligned}
$$

Energy retention was calculated as the difference between daily MEI and mean HP during the 5-d balance period. Energy retained as protein was calculated as nitrogen retention (g) $\times 6.25 \times 23.8(\mathrm{~kJ} / \mathrm{g})$ according to Chwalibog et al [23]. Energy retained as fat was calculated as the difference between total energy retention and the energy retained as protein.

\section{Statistical analysis}

Data were analyzed using PROC general linear model procedure in SAS (SAS Institute Inc., Cary, NC, USA) as a randomized complete block design. The individual pig was used as the experimental unit for all response variables in the model, which included feeding level as the main effect. Orthogonal polynomial contrasts were used to examine linear and quadratic effects of feeding level on growth performance, ATTD values, energy, and nitrogen balance in growing pigs. Differences were considered significant at $p \leq 0.05$, whereas tendencies were discussed at $p>0.05$ but $p \leq 0.10$. Linear regression analyses were conducted by OriginPro 8.5 (OriginLab, Northampton, MA, USA) to determine the relationship between ADG $(\mathrm{g}), \mathrm{RE}_{\mathrm{p}}(\mathrm{g} / \mathrm{d})$ or $\mathrm{RE}_{\mathrm{f}}(\mathrm{g} / \mathrm{d})$ and MEI $\left(\mathrm{kJ} / \mathrm{kg} \mathrm{BW} \mathrm{W}^{0.60} \mathrm{~d}\right)$.

\section{RESULTS}

\section{Growth performance and nutrient utilization}

All pigs were healthy, and the experiment was carried out with all animals in a normal physiological state. The effects of feeding level on growth performance, ATTD of DM, GE, and CP and energy values of the diet are presented in Table 2. The final BW and ADG linearly increased as feeding level increases $(p<0.010)$. The G:F improved linearly with increase in feed intake $(p=0.025)$. However, there were no difference for ATTD of DM, GE, and $\mathrm{CP}$ with increasing dietary energy intake. The DE and ME content had no association with feeding level. There was little evidence of an association between ME:DE

Table 2. Effects of feeding level on growth performance, apparent total tract digestibility of nutrients and energy and energy values of diets in growing pigs ${ }^{1)}$

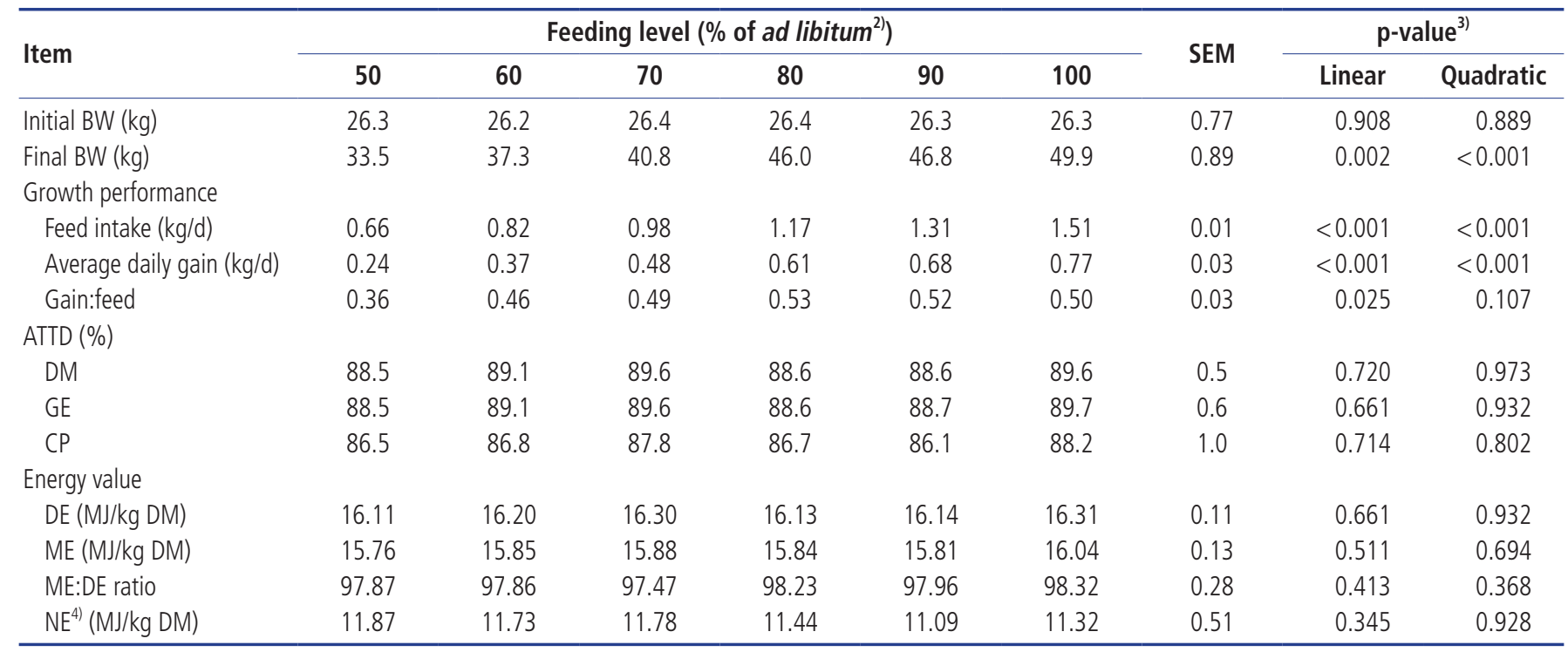

ATTD, apparent total tract digestibility; SEM, standard error of the mean; BW, body weight; DM, dry matter; GE, gross energy; CP, crude protein; DE, digestible energy; ME, metabolizable energy; $\mathrm{NE}$, net energy.

1) Data are means of 6 replicates per treatment.

2) The estimated ad libitum ME intake was $2,400 \mathrm{~kJ} / \mathrm{kg} \mathrm{BW}^{0.60} \mathrm{~d}$.

${ }^{3)}$ Linear and quadratic contrasts for feeding level.

4) Net energy requirement for maintenance was obtained from Noblet et al [15]. 
Table 3. Effects of feeding level on energy and nitrogen balance and energy retention in growing pigs ${ }^{11}$

\begin{tabular}{|c|c|c|c|c|c|c|c|c|c|}
\hline \multirow{2}{*}{ Item } & \multicolumn{6}{|c|}{ Feeding level ( $\%$ of ad libitum $\left.{ }^{2}\right)$} & \multirow{2}{*}{ SEM } & \multicolumn{2}{|c|}{ p-value ${ }^{3)}$} \\
\hline & 50 & 60 & 70 & 80 & 90 & 100 & & Linear & Quadratic \\
\hline \multicolumn{10}{|l|}{ Energy balance $\left(\mathrm{kJ} / \mathrm{kg} \mathrm{BW}{ }^{0.60} \mathrm{~d}\right)$} \\
\hline ME intake & 1,207 & 1,440 & 1,671 & 1,906 & 2,116 & 2,368 & 12 & $<0.001$ & 0.909 \\
\hline Total heat production & 953 & 1,006 & 1,046 & 1,113 & 1,214 & 1,266 & 42 & 0.001 & 0.545 \\
\hline Oxidation of protein & 106 & 112 & 119 & 145 & 139 & 172 & 23 & 0.206 & 0.705 \\
\hline Oxidation of carbohydrate & 824 & 876 & 895 & 936 & 1,042 & 1,057 & 49 & 0.023 & 0.713 \\
\hline \multicolumn{10}{|l|}{ Nitrogen balance (g/d) } \\
\hline Intake & 18.2 & 21.7 & 25.3 & 29.0 & 33.1 & 36.6 & 0.4 & $<0.001$ & 0.547 \\
\hline Fecal excretion & 2.4 & 2.8 & 3.0 & 3.4 & 4.6 & 3.9 & 0.4 & 0.010 & 0.585 \\
\hline Urinary excretion & 7.3 & 7.7 & 8.6 & 10.0 & 10.3 & 13.2 & 1.6 & 0.109 & 0.505 \\
\hline Retention & 8.5 & 11.2 & 13.7 & 15.6 & 18.2 & 19.6 & 1.6 & 0.002 & 0.673 \\
\hline \multicolumn{10}{|l|}{ Energy retention $\left(\mathrm{kJ} / \mathrm{kg} \mathrm{BW} W^{0.60} \mathrm{~d}\right)$} \\
\hline $\mathrm{RE}_{\mathrm{p}}$ & 152 & 205 & 249 & 269 & 318 & 332 & 29 & 0.006 & 0.502 \\
\hline $\mathrm{RE}_{f}$ & 116 & 254 & 398 & 534 & 613 & 701 & 51 & $<0.001$ & 0.290 \\
\hline Total & 268 & 459 & 648 & 803 & 932 & 1,033 & 44 & $<0.001$ & 0.103 \\
\hline Respiratory quotient & 1.02 & 1.03 & 1.06 & 1.06 & 1.08 & 1.08 & 0.01 & 0.006 & 0.135 \\
\hline Non-protein respiratory quotient & 1.02 & 1.04 & 1.08 & 1.10 & 1.11 & 1.12 & 0.01 & 0.001 & 0.099 \\
\hline
\end{tabular}

$S E M$, standard error of the mean; $B W$, body weight; $M E$, metabolizable energy; $R E_{p}$ energy retained as protein; $R E_{f}$, energy retained as fat.

1) Data are means of 6 replicates per treatment.

${ }^{2)}$ The estimated ad libitum ME intake was 2,400 kJ/kg BW.60 d.

${ }^{3)}$ Linear and quadratic contrasts for feeding level.

ratio and level of dietary energy intake.

\section{Energy and nitrogen balance}

The effects of feeding level on energy and nitrogen balance and energy retention in growing pigs are shown in Table 3. There was a linear increase in total HP from $953 \mathrm{~kJ} / \mathrm{kg} \mathrm{BW}^{0.60} \mathrm{~d}$ to $1,266 \mathrm{~kJ} / \mathrm{kg} \mathrm{BW}{ }^{0.60} \mathrm{~d}$ as feeding level increases $(\mathrm{p}=0.001)$ from $50 \%$ to $100 \%$ of ad libitum intake. When the total HP was partitioned into heat production from OXP and $\mathrm{OXCHO}$, the OXP had no association with increasing dietary energy intake. However, for $\mathrm{OXCHO}$, a linear increase was observed as feed-

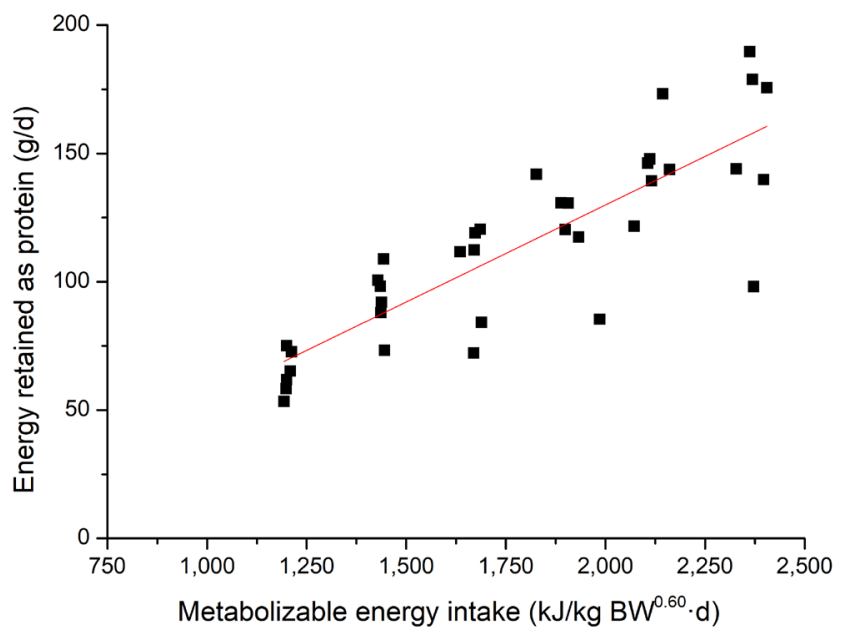

Figure 1. Linear relationship (parameters \pm standard error) between metabolizable energy intake (MEI) and energy retained as protein $\left(R E_{p}\right)$ for all pigs $(\mathbf{\square})$. $R E_{p} g / d=$ $0.076( \pm 0.008) \times \mathrm{MEI}, \mathrm{kJ} / \mathrm{kg} \mathrm{BW}{ }^{0.60} \mathrm{~d}-21.28( \pm 15.286), R^{2}=0.71, p<0.01, \mathrm{n}=36$. ing level increases $(\mathrm{p}=0.023)$. Nitrogen intake and excreted in feces linearly increased $(\mathrm{p}<0.010)$ as dietary ME increases. However, nitrogen excreted in urine had no association with dietary energy. Nitrogen retention also showed a positive linear response $(p=0.002)$ with increasing levels of feed intake. Energy retention, when expressed as protein, fat or total, linearly increased as feeding level increases $(\mathrm{p}<0.001)$. To determine the effect of feeding level on the energy retention for fat and protein in growing pigs, linear regressions of REp and REf in growing pigs were performed and presented in Figure 1 and 2. The equations (parameters \pm standard error $[\mathrm{SE}]$ ) for $\mathrm{RE}_{\mathrm{p}}$ and

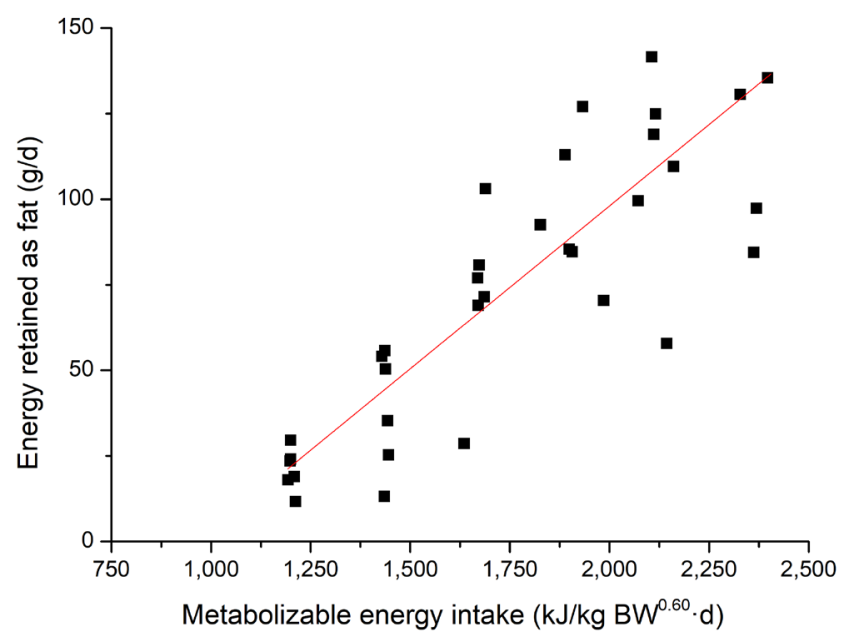

Figure 2. Linear relationship (parameters \pm standard error) between metabolizable energy intake (MEI) and energy retained as fat $\left(R E_{f}\right)$ for all pigs ( $\left.\mathbf{\square}\right)$. $R E_{f} g / d=0.095$ $( \pm 0.009) \times M E l, k J / k g ~ B W 0.60 d-92.21( \pm 17.189), R^{2}=0.75, p<0.01, n=36$. 
$\mathrm{RE}_{\mathrm{f}}$ were $\mathrm{RE}_{\mathrm{p}}, \mathrm{g} / \mathrm{d}=0.076( \pm 0.008) \times \mathrm{MEI}, \mathrm{kJ} / \mathrm{kg} \mathrm{BW} \mathrm{B}^{0.60} \mathrm{~d}-21.28$ $( \pm 15.286)\left(\mathrm{R}^{2}=0.71, \mathrm{p}<0.001\right)$ and $\mathrm{RE}_{\mathrm{f}} \mathrm{g} / \mathrm{d}=0.095( \pm 0.009) \times$ MEI, kJ/kg BW ${ }^{0.60} \mathrm{~d}-92.21( \pm 17.189)\left(\mathrm{R}^{2}=0.75, \mathrm{p}<0.001\right)$, respectively. A linear response was observed for the RQ and $\mathrm{RQ}_{\mathrm{np}}$ as MEI increases $(\mathrm{p}<0.010)$.

\section{Serum biochemical parameters related to energy metabolism}

The effects of feeding level on the concentration of serum biochemical parameters in growing pigs are shown in Table 4 . The BHBA concentration tended to increase with increasing feed intake $(\mathrm{p}=0.080)$. However, glucose, SUN, creatinine, triglyceride, FFA, and leptin concentrations showed little association with dietary energy intake.

\section{Energy requirement for maintenance}

Linear regressions of MEI $\left(\mathrm{kJ} / \mathrm{kg} \mathrm{BW}^{0.60} \mathrm{~d}\right)$ against ADG $(\mathrm{g} / \mathrm{d})$ are presented in Figure 3. The regression equations (parameters \pm SE) were MEI, $\mathrm{kJ} / \mathrm{kg} \mathrm{BW}{ }^{0.60} \mathrm{~d}=1.88( \pm 0.128) \times \mathrm{ADG}, \mathrm{g} / \mathrm{d}+$ $782( \pm 72.848), \mathrm{R}^{2}=0.86, \mathrm{p}<0.001$. The calculated $\mathrm{ME}_{\mathrm{m}}$ in this study was $782 \mathrm{~kJ} / \mathrm{kg} \mathrm{BW}^{0.60} \mathrm{~d}$ from Figure 3. Specifically, combined with the equations for energy retained as protein and fat, if the ME supplied to growing pigs is about $782 \mathrm{~kJ} / \mathrm{kg}$ $\mathrm{BW}^{0.60} \mathrm{~d}$, protein retention of pigs would be positive while fat retention of pigs would be negative.

\section{DISCUSSION}

Growth performance and nutrient utilization

Increasing feed intake increased not only MEI, but also other nutrients such as protein. Thus, effects of feeding level on ATTD of energy and nutrients were determined. The ATTD of DM, GE, and CP were not affected by an increase in feeding level. This result is supported by the research of Peers et al [24] who assessed the digestibility of DM, GE, and total nitrogen in barley and some of the findings of Zhang et al [14] who estimated the effects of previous feeding level on nutrient

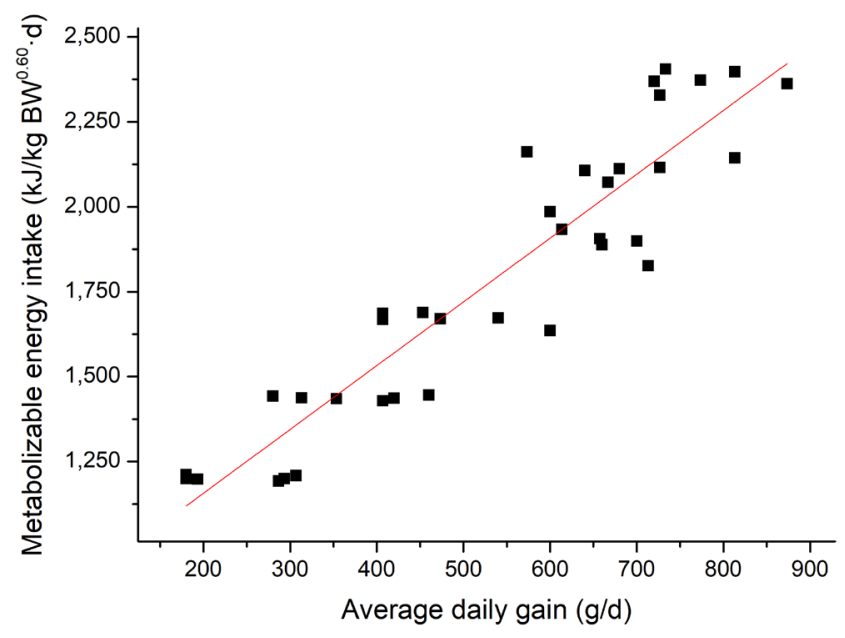

Figure 3. Linear relationship (parameters \pm standard error) between metabolizable energy intake (MEI) and average daily gain (ADG) for all pigs (घ). MEl, $\mathrm{kJ} / \mathrm{kg} \mathrm{BW}{ }^{0.60} \mathrm{~d}$ $=1.88( \pm 0.128) \times A D G, g / d+782( \pm 72.848), R^{2}=0.86, p<0.01, n=36$.

utilization in pigs. However, our results were in contrast with the observations of Goerke et al [9] that the ATTD of DM, CP, organic matter, ash, and GE decreased in diets as the feeding level increases. The relationship between feeding level and digestibility of nutrients appears to depend on the characteristic of the feed [10]. Dietary fiber is one of the main components in the diet which affects digestibility because higher dietary fiber is inefficiently degradative and makes digesta rapidly pass through the gastrointestinal tract [24,25]. In the present study, the type of dietary fiber was the same for all treatments and the concentration of fiber was lower than in the diets used by Goerke et al [9]. Therefore, this may be explained that dietary feeding level had no difference in the ATTD of DM, GE, and $\mathrm{CP}$ in the present study.

Digestible energy and ME of diets were not affected by the feeding level, which were in agreement with results obtained in previous studies [3,24]. Similarly, Lovatto et al [26] investigated the effects of feed restriction and subsequent refeeding

Table 4. Effects of feeding level on the concentration of serum biochemical parameters in growing pigs ${ }^{11}$

\begin{tabular}{|c|c|c|c|c|c|c|c|c|c|}
\hline \multirow{2}{*}{ Item } & \multicolumn{6}{|c|}{ Feeding level $\left(\%\right.$ of ad libitum $\left.{ }^{2}\right)$} & \multirow{2}{*}{ SEM } & \multicolumn{2}{|c|}{ p-value ${ }^{3)}$} \\
\hline & 50 & 60 & 70 & 80 & 90 & 100 & & Linear & Quadratic \\
\hline Glucose (mmol/L) & 4.63 & 5.52 & 4.96 & 5.12 & 5.10 & 5.07 & 0.31 & 0.700 & 0.767 \\
\hline Urea nitrogen (mmol/L) & 1.53 & 2.38 & 1.71 & 1.77 & 1.87 & 2.25 & 0.35 & 0.543 & 0.771 \\
\hline Creatinine (mmol/L) & 56.42 & 73.21 & 65.39 & 58.73 & 60.75 & 59.18 & 7.83 & 0.917 & 0.340 \\
\hline Triglyceride (mmol/L) & 0.23 & 0.22 & 0.21 & 0.22 & 0.22 & 0.29 & 0.04 & 0.301 & 0.284 \\
\hline Free fatty acids (mmol/L) & 0.53 & 0.50 & 0.48 & 0.41 & 0.49 & 0.51 & 0.04 & 0.175 & 0.761 \\
\hline$\beta$-hydroxybutyric acid (mmol/L) & 0.13 & 0.11 & 0.13 & 0.12 & 0.12 & 0.13 & 0.01 & 0.080 & 0.889 \\
\hline Leptin $(\mu \mathrm{g} / \mathrm{L})$ & 6.63 & 6.82 & 6.64 & 6.75 & 8.07 & 6.98 & 0.56 & 0.238 & 0.129 \\
\hline
\end{tabular}

SEM, standard error of the mean.

1) Data are means of 6 replicates per treatment.

${ }^{2)}$ The estimated ad libitum metabolizable energy intake was $2,400 \mathrm{~kJ} / \mathrm{kg} \mathrm{BW}{ }^{0.60} \mathrm{~d}$

${ }^{3)}$ Linear and quadratic contrasts for feeding level. 
on energy utilization in growing pigs, and no differences were observed in energy digestibility during feed restriction. Different feeding levels had no effect on the value of ME:DE ratio, which agrees with previous observations in growing pigs [9]. The ME:DE ratio is related to the protein content of the diet and the amount of nitrogen in urine $[27,28]$. In the current study, nitrogen excreted in urine as a proportion of nitrogen intake had no association with dietary energy intake, which may explain the results of the ME:DE ratio [25].

The ADG in the present study was $773 \mathrm{~g} / \mathrm{d}$ at the $100 \%$ feeding level, whereas ADG in previous studies ranged from 560 to $900 \mathrm{~g} / \mathrm{d}$ [29-31]. The ADG improved as the feeding level increased. Similar results have been reported by Campbell and Dunkin [32] and Quiniou et al [33]. The findings of the current study suggested that the dietary energy content was higher than $\mathrm{ME}_{\mathrm{m}}$ and anabolism exceeded catabolism [34].

\section{Energy and nitrogen balance}

The growth of pigs is a dynamic process of quantitative inputs and outputs of carbohydrate, protein and fat, which can be measured by gas exchange calorimetry or carbon-nitrogen balance [35]. The HP is described as the energy lost and not retained in the ME $[3,36]$. In the present study, the HP of different feeding levels were mainly provided by $\mathrm{OXCHO}$, which accounted for about $86 \%$ of the total HP, while the HP from OXP was only $11 \%$ of total HP. Similarly, Chwalibog et al [21] reported that the proportion of carbohydrate oxidation during feeding was about $90 \%$, and protein oxidation accounted for only about $9 \%$. Therefore, the HP and OXCHO increased as feeding level increases.

Energy retention is the fraction of ME retained in the body during feeding. The retention of protein and fat were $159 \mathrm{~g} / \mathrm{d}$ and $133 \mathrm{~g} / \mathrm{d}$, respectively, when pigs were fed ad libitum. Fat deposition was slightly lower than Quiniou et al [33] and de Lange et al [3], which may be a result of the younger pigs used in the present study. However, if expressed as $\mathrm{kJ} / \mathrm{kg} \mathrm{BW}{ }^{0.60} \mathrm{~d}$, the value of $\mathrm{RE}_{\mathrm{p}}$ was higher than fat at lower feeding levels, but lower at higher feeding levels. This may be explained by the fact that pigs give preference to use dietary energy to synthesize protein $[34,37,38]$, and fat formation increases when energy intake is above the requirement for maintenance and maximal muscle formation [39]. Some equations that described the relationship between $\mathrm{RE}_{\mathrm{p}}$ or $\mathrm{RE}_{\mathrm{f}}$ and MEI have been established based on comparative slaughter [33,40]. However, considering that comparative slaughter is labor intensive and requires a large number of animals, indirect calorimetry was used for measurement of energy retention [41], though the latter generally estimated higher energy and protein retention than comparative slaughter [37]. From previous equations and the equations established in the current studies, daily $\mathrm{RE}_{\mathrm{p}}$ increased linearly with MEI [33]. However, several studies have proposed that there was a linear-plateau relationship between energy intake and the rate of protein deposition [42], which were not determined in the current study. This could be partly explained that daily $\mathrm{RE}_{\mathrm{p}}$ did not reach the maximum under the current ad libitum feeding level [43]. Meanwhile, the increase in $R Q$ and $R Q_{n p}$ which was observed as MEI increased reflects the elevation in body fat gain $[3,20]$.

\section{Serum biochemical parameters related to energy metabolism}

The BHBA is one of the important intermediate metabolites of fatty acid oxidation in the liver [44]. Levels of BHBA increase in the liver, heart, muscle, brain, and other tissues with calorie restriction and fasting [45]. In the current experiment, the feeding level had no difference but there was a linear trend on the concentration of BHBA, which may be explained by the fact that the lowest feeding level fed to pigs was higher than $\mathrm{ME}_{\mathrm{m}}$. Serum urea nitrogen concentration can be an indirect indicator of the AA utilization in the diet, as increases in SUN reflect reduced efficiency of nitrogen utilization and more synthesis of urea [46]. In the present research, SUN concentrations of pigs were also not different, which indicated that the efficiency of nitrogen utilization was not affected by the feeding level when the MEI of growing pigs was higher than $\mathrm{ME}_{\mathrm{m}}$.

\section{Energy requirement for maintenance}

Based on the linear regression analyses, the estimated $\mathrm{ME}_{\mathrm{m}}$ in present study was $782 \mathrm{~kJ} / \mathrm{kg} \mathrm{BW}^{0.60} \mathrm{~d}$. The $\mathrm{ME}_{\mathrm{m}}$ was close to the value $\left(774 \mathrm{~kJ} / \mathrm{kg} \mathrm{BW}^{0.60} \mathrm{~d}\right)$ reported by de Lange et al [3] who calculated $\mathrm{ME}_{\mathrm{m}}$ from energy retention. Energy requirement for maintenance of other studies ranged from 720 to $1,120 \mathrm{~kJ} / \mathrm{kg} \mathrm{BW}^{0.60} \mathrm{~d}[1-3,47]$. However, the $\mathrm{ME}_{\mathrm{m}}$ was lower than the results of Wisesmuller et al [38], which may be explained by the fact that the content of dietary crude fiber in the current experiment was lower $(2.75 \%$ vs $9.0 \%)$. As previously mentioned, when estimated $\mathrm{ME}_{\mathrm{m}}$ was substituted into the equations of energy retention for fat and protein, protein retention of pigs would be positive while fat retention of pigs would be negative. Our results suggested that growing pigs tend to deposit protein at the expense of fat at estimated maintenance state. These results were consistent with the reports of Quiniou et al [33] who performed regression analysis between protein or lipid deposition and MEI above maintenance. Evidences suggested that energy utilization for maintenance is partly related to protein turnover because proteins are essential parts of organisms and perform a vast array of functions within cells $[48,49]$. However, fat is a main source to meet the energy requirements when the energy supply is restricted, which is a wise strategy for saving glucose and protein to important organs and tissues in the body [50]. But even so, it was a pity that serum biochemical parameters, which were associated with protein and fat metabolism, were little influenced 
by feeding level $[45,46]$. Therefore, further research is needed to reveal the metabolism for process of maintenance.

\section{CONCLUSION}

In the present study, energy requirement for maintenance was estimated at $782 \mathrm{~kJ} / \mathrm{kg} \mathrm{BW}^{0.60} \mathrm{~d}$ based on linear regression analyses. This indicates that growing pigs will deposit protein and mobilize fat if MEI is close to estimated requirement for maintenance.

\section{CONFLICT OF INTEREST}

We certify that there is no conflict of interest with any financial organization regarding the material discussed in the manuscript.

\section{ACKNOWLEDGMENTS}

This study was financially supported by the National Natural Science Foundation of China (31372317), Animal Health Feeding Model Research and Demonstration (2012BAD39B03), Prevention and Control of Nutritional Metabolism and Toxic Diseases in Livestock and Poultry (2016YFD0501204-1) and the 111 Project (B16044).

\section{REFERENCES}

1. Noblet J, Karege C, Dubois S, van Milgen J. Metabolic utilization of energy and maintenance requirements in growing pigs: effects of sex and genotype. J Anim Sci 1999;77:1208-16. https:// doi.org/10.2527/1999.7751208x

2. ARC. The nutrient requirements of pigs. Slough, UK: Commonwealth Agricultural Bureaux; 1981.

3. de Lange K, van Milgen J, Noblet J, Dubois S, Birkett S. Previous feeding level influences plateau heat production following a $24 \mathrm{~h}$ fast in growing pigs. Br J Nutr 2006;95:1082-7. https:// doi.org/10.1079/BJN20061748

4. Zemmelink G, Tolkamp BJ, Ogink NWM. Energy requirements for maintenance and gain of West African Dwarf goats. Small Rumin Res 1991;5:205-15. https://doi.org/10.1016/09214488(91)90125-A

5. Early RJ, Mahgoub O, Lu CD. Energy and protein utilization for maintenance and growth in Omani ram lambs in hot climates. I. Estimates of energy requirements and efficiency. J Agric Sci 2001;136:451-9. https://doi.org/10.1017/S00218596 01008899

6. Yuliarty, Low S, Fisher J, Dryden GM. Energy requirements for maintenance and growth of entire male Bali cattle in East Timor. Anim Prod Sci 2014;54:908-14. https://doi.org/10.1071/ AN13092

7. Luo J, Goetsch AL, Sahlu T, et al. Prediction of metabolizable energy requirements for maintenance and gain of preweaning, growing and mature goats. Small Rumin Res 2004;53:231-52. https://doi.org/10.1016/j.smallrumres.2004.04.006

8. Liu DW, Jaworski NW, Zhang GF, Li Z, Li D, Wang F. Effect of experimental methodology on fasting heat production and the net energy content of corn and soybean meal fed to growing pigs. Arch Anim Nutr 2014;68:281-95. https://doi.org/10.10 80/1745039X.2014.931016

9. Goerke M, Mosenthin R, Jezierny D, et al. Effect of feeding level on ileal and total tract digestibility of nutrients and energy from soybean meal-based diets for piglets. J Anim Physiol Anim Nutr 2014;98:1154-65. https://doi.org/10.1111/jpn.12174

10. Morel PCH, Lee TS, Moughan PJ. Effect of feeding level, live weight and genotype on the apparent faecal digestibility of energy and organic matter in the growing pig. Anim Feed Sci Technol 2006;126:63-74. https://doi.org/10.1016/j.anifeedsci. 2005.06.006

11.van Milgen J, Bernier JF, Lecozler Y, Dubois S, Noblet J. Major determinants of fasting heat production and energetic cost of activity in growing pigs of different body weight and breed/ castration combination. Br J Nutr 1998;79:509-17.

12. Inoue $H$, Watanuki M, Myint HT, Ito T, Kuwayama $H$, Hidari $\mathrm{H}$. Effects of fasting and refeeding on plasma concentrations of leptin, ghrelin, insulin, growth hormone and metabolites in swine. Anim Sci J 2005;76:367-74. https://doi.org/10.1111/ j.1740-0929.2005.00277.x

13. Moro T, Tinsley G, Bianco A, et al. Effects of eight weeks of time-restricted feeding (16/8) on basal metabolism, maximal strength, body composition, inflammation, and cardiovascular risk factors in resistance-trained males. J Transl Med 2016;14: 290. https://doi.org/10.1186/s12967-016-1044-0

14.Zhang GF, Liu DW, Wang FL, Li DF. Estimation of the net energy requirements for maintenance in growing and finishing pigs. J Anim Sci 2014;92:2987-95. https://doi.org/10.2527/jas. 2013-7002

15. Noblet J, Fortune H, Shi XS, Dubois S. Prediction of net energy value of feeds for growing pigs. J Anim Sci 1994;72:344-54. https://doi.org/10.2527/1994.722344x

16. AOAC International. Official methods of analysis of AOAC international. 18th ed. Gaithersburg, MD, USA: AOAC International; 2007.

17. Thiex NJ, Anderson S, Gildemeister B. Crude fat, diethyl ether extraction, in feed, cereal grain, and forage (Randall/Soxtec/ submersion method): collaborative study. J AOAC Int 2003; 86:888-98.

18. Li P, Li DF, Zhang HY, et al. Determination and prediction of energy values in corn distillers dried grains with solubles sources with varying oil content for growing pigs. J Anim Sci 2015;93:3458-70. https://doi.org/10.2527/jas.2014-8782

19. Adeola O. Digestion and balance techniques in pigs. In: Lewis AJ, Southern LL, editors. Swine nutrition. Washington, DC, USA: CRC Press; 2001. p. 903-16. 
20. Brouwer E. Report of sub-committee on constants and factors. In: Proceedings of the 3rd EAAP Symposium on Energy Metabolism 1965. London, UK: Academic Press; 1965. p. 442-3.

21. Chwalibog A, Tauson AH, Thorbek G. Energy metabolism and substrate oxidation in pigs during feeding, starvation and re-feeding. J Anim Physiol Anim Nutr (Berl) 2004;88:10112. https://doi.org/10.1111/j.1439-0396.2003.00465.x

22. Chwalibog A, Thorbek G. Quantitative partition of protein, carbohydrate and fat pools in growing pigs. Arch Anim Nutr 1995;48:53-61.

23. Chwalibog A, Jakobsen K, Tauson AH, Thorbek G. Energy metabolism and nutrient oxidation in young pigs and rats during feeding, starvation and re-feeding. Comp Biochem Physiol A Mol Integr Physiol 2005;140:299-307. https://doi. org/10.1016/j.cbpb.2005.01.010

24. Peers DG, Taylor AG, Whittemore CT. The influence of feeding level and level of dietary inclusion on the digestibility of barley meal in the pig. Anim Feed Sci Technol 1977;2:41-7. https:// doi.org/10.1016/0377-8401(77)90039-6

25. Noblet J, Perez JM. Prediction of digestibility of nutrients and energy values of pig diets from chemical analysis. J Anim Sci 1993;71:3389-98. https://doi.org/10.2527/1993.71123389x

26. Lovatto PA, Sauvant D, Noblet J, Dubois S, van Milgen J. Effects of feed restriction and subsequent refeeding on energy utilization in growing pigs. J Anim Sci 2006;84:3329-36. https:// doi.org/10.2527/jas.2006-048

27. Noblet J, Henry Y. Energy evaluation systems for pig diets - a review. Livest Prod Sci 1993;36:121-41. https://doi.org/10. 1016/0301-6226(93)90147-A

28.Le Goff G, Noblet J. Comparative total tract digestibility of dietary energy and nutrients in growing pigs and adult sows. J Anim Sci 2001;79:2418-27. https://doi.org/10.2527/2001.79 92418x

29. Liu XT, Ma WF, Zeng XF, et al. Estimation of the standardized ileal digestible valine to lysine ratio required for 25-to 120-kilogram pigs fed low crude protein diets supplemented with crystalline amino acids. J Anim Sci 2015;93:4761-73. https://doi. org/10.2527/jas.2015-9308

30. Tian YY, Gong LM, Xue JX, Cao J, Zhang LY. Effects of graded levels of chromium methionine on performance, carcass traits, meat quality, fatty acid profiles of fat, tissue chromium concentrations, and antioxidant status in growing-finishing pigs. Biol Trace Elem Res 2015;168:110-21. https://doi.org/10.1007/ s12011-015-0352-1

31. Wu F, Johnston LJ, Urriola PE, Hilbrands AM, Shurson GC. Effects of feeding diets containing distillers' dried grains with solubles and wheat middlings with equal predicted dietary net energy on growth performance and carcass composition of growing-finishing pigs. J Anim Sci 2016;94:144-54. https:// doi.org/10.2527/jas.2015-9592

32. Campbell RG, Dunkin AC. The influence of dietary protein and energy intake on the performance, body composition and energy utilization of pigs growing from 7 to $19 \mathrm{~kg}$. Anim Sci 1983;36:185-92. https://doi.org/10.1017/S1357729800001235

33. Quiniou N, Dourmad JY, Noblet J. Effect of energy intake on the performance of different types of pig from 45 to $100 \mathrm{~kg}$ body weight. 1. Protein and lipid deposition. Anim Sci 1996; 63:277-88. https://doi.org/10.1017/S1357729800014831

34. Velayudhan DE, Kim IH, Nyachoti CM. Characterization of dietary energy in Swine feed and feed ingredients: a review of recent research results. Asian-Australas J Anim Sci 2015;28: 1-13. https://doi.org/10.5713/ajas.14.0001R

35. Chwalibog A, Jakobsen K, Henckel S, Thorbek G. Estimation of quantitative oxidation and fat retention from carbohydrate, protein and fat in growing pigs. J Anim Physiol Anim Nutr 1992;68:123-35. https://doi.org/10.1111/j.1439-0396.1992. tb00652.x

36. Van Milgen J, Noblet J. Partitioning of energy intake to heat, protein, and fat in growing pigs. J Anim Sci 2003;81(Suppl 2): E86-E93.https://doi.org/10.2527/2003.8114_suppl_2E86x

37. Black JL. Manipulation of body composition through nutrition. In: Proceedings of the Australian Society of Animal Production 2009; 2009 Feb; Sydney, Australia. Armidale NSW, Australia: ASAP; 1974. pp. 211-8.

38. Wiesemüller W, Poppe S, Hackl W. Studies of the energy metabolism of pigs at a feeding level at live weight equilibrium. Arch Anim Nutr 1988;38:603-17.

39. Just A. Nutritional manipulation and interpretation of body compositional differences in growing swine. J Anim Sci 1984; 58:740-52. https://doi.org/10.2527/jas1984.583740x

40. Campbell RG, Taverner MR, Curic DM. The influence of feeding level from 20 to $45 \mathrm{~kg}$ live weight on the performance and body composition of female and entire male pigs. Anim Sci 1983;36:193-9. https://doi.org/10.1017/S1357729800001247

41. Ayoade DI, Kiarie E, Neto MAT, Nyachoti CM. Net energy of diets containing wheat-corn distillers dried grains with solubles as determined by indirect calorimetry, comparative slaughter, and chemical composition methods. J Anim Sci 2012;90:43739. https://doi.org/10.2527/jas.2011-4858

42.van Milgen J, Noblet J. Energy partitioning in growing pigs: the use of a multivariate model as an alternative for the factorial analysis. J Anim Sci 1999;77:2154-62. https://doi.org/ 10.2527/1999.7782154x

43. Campbell RG, Taverner MR, Curic DM. Effects of sex and energy intake between 48 and $90 \mathrm{~kg}$ live weight on protein deposition in growing pigs. Anim Sci 1985;40:497-503. https:// doi.org/10.1017/S0003356100040198

44.Laeger T, Metges CC, Kuhla B. Role of beta-hydroxybutyric acid in the central regulation of energy balance. Appetite 2010; 54:450-5. https://doi.org/10.1016/j.appet.2010.04.005

45.Sleiman SF, Henry J, Al-Haddad R, et al. Exercise promotes the expression of brain derived neurotrophic factor (BDNF) through the action of the ketone body beta-hydroxybutyrate. Elife 2016;5:e15092. https://doi.org/10.7554/eLife.15092 
46. Whang KY, Easter RA. Blood urea nitrogen as an index of feed efficiency and lean growth potential in growing-finishing swine. Asian-Australas J Anim Sci 2000;13:811-6. https://doi.org/10. 5713/ajas.2000.811

47.Labussiere E, van Milgen J, de Lange CFM, Noblet J. Maintenance energy requirements of growing pigs and calves are influenced by feeding level. J Nutr 2011;141:1855-61. https://doi. org/10.3945/jn.111.141291

48. Kil DY, Kim BG, Stein HH. Feed energy evaluation for growing pigs. Asian-Australas J Anim Sci 2013;26:1205-17. https:// doi.org/10.5713/ajas.2013.r.02

49. Bunaciu AA, Aboul-Enein HY, Hoang VD. Raman spectroscopy for protein analysis. Appl Spectrosc Rev 2015;50:37786. https://doi.org/10.1080/05704928.2014.990463

50.Lomb DJ, Laurent G, Haigis MC. Sirtuins regulate key aspects of lipid metabolism. Biochim Biophys Acta Proteins Proteom 2010;1804:1652-7. https://doi.org/10.1016/j.bbapap.2009.11.021

51. NRC. Nutrient requirements of swine, eleventh revised editon. Washington, DC, USA: National Academy Press; 2012. 